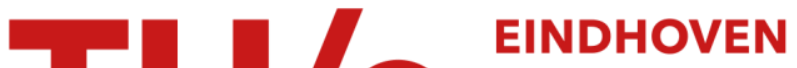 \\ UNIVERSITY OF \\ TECHNOLOGY
}

\section{Firms' perceived benefits of shared facilities on Dutch science parks: empirical evidence}

Citation for published version (APA):

Junker, T. R., Ng, W. K. B., Appel - Meulenbroek, H. A. J. A., \& Arentze, T. A. (2018). Firms' perceived benefits of shared facilities on Dutch science parks: empirical evidence. Abstract from 25th Annual European Real Estate Society Conference (ERES 2018), Reading, United Kingdom.

Document status and date:

Published: 28/06/2018

\section{Document Version:}

Publisher's PDF, also known as Version of Record (includes final page, issue and volume numbers)

\section{Please check the document version of this publication:}

- A submitted manuscript is the version of the article upon submission and before peer-review. There can be important differences between the submitted version and the official published version of record. People interested in the research are advised to contact the author for the final version of the publication, or visit the $\mathrm{DOI}$ to the publisher's website.

- The final author version and the galley proof are versions of the publication after peer review.

- The final published version features the final layout of the paper including the volume, issue and page numbers.

Link to publication

\section{General rights}

Copyright and moral rights for the publications made accessible in the public portal are retained by the authors and/or other copyright owners and it is a condition of accessing publications that users recognise and abide by the legal requirements associated with these rights.

- Users may download and print one copy of any publication from the public portal for the purpose of private study or research.

- You may not further distribute the material or use it for any profit-making activity or commercial gain

- You may freely distribute the URL identifying the publication in the public portal.

If the publication is distributed under the terms of Article 25fa of the Dutch Copyright Act, indicated by the "Taverne" license above, please follow below link for the End User Agreement:

www.tue.nl/taverne

Take down policy

If you believe that this document breaches copyright please contact us at:

openaccess@tue.nl

providing details and we will investigate your claim. 


\section{EUROPEAN \\ REAL ESTATE \\ SOCIETY \\ 25th Annual Conference \\ Henley \\ UNIVERSITY OF READING \\ June 27 - 30, 2018, Reading, \\ United Kingdom.}

\section{Abstracts}

You have requested the abstract for paper number 105:

Robin Junker, Wei Keat Benny Ng, Rianne Appel-Meulenbroek, Theo Arentze, Eindhoven University of Technology, Eindhoven, The Netherlands

Firms' perceived benefits of shared facilities on Dutch science parks: empirical evidence. (assigned to theme $\underline{\mathbf{A}-1}$ )

Science parks as area developments have existed for decades and have captivated the attention of academics and policy-makers for their supposedly positive impact on resident organisations and regions. To date there is mixed empirical evidence to indicate the performance enhancing effects of specific science park features on research \& development, economic output or improved collaboration between users. Furthermore, limited attention is given to the demands and perceptions of science park users. This study focuses on one of the main features of science parks, namely the shared facilities and services on-site and how users perceive the benefits of these facilities. An online survey is distributed to 594 resident organisations on eight science parks in the Netherlands to which 112 participated. Within the questionnaire respondents are inquired on organisational characteristics in order to distinguish tenant types through clustering on aspects, such as R\&D activity, organisation size, sector diversity. Then respondents indicate the benefits they perceive for specific presented shared facilities and services retrieved from science park literature based on their importance. Finally, respondents indicated meaningful associations between shared facilities and benefits. Results show that among resident organisations three distinguishable clusters emerge; non-R\&D organisations', R\&D start-ups', and R\&D small-medium enterprises' with each cluster mentioning different benefits that they value. In general, knowledge sharing and on-site collaboration are most frequently mentioned as important science park benefits and are mostly associated to training programs and information access. Both R\&D start-ups' and non-R\&D organisations' value the opportunity to be near customers for different reasons, while R\&D small medium entrepreneurs' perceive social events as a means to be close to the university or other higher educational institutions. The associations between various types of shared facilities and benefits that residents seek provide insights for practitioners in terms of the design and management of science parks and add to the body of knowledge of science park literature.

Vienna University of Economics and Business Research Institute for Spatial and Real Estate Economics Conference organized through conf-vienna (copyright Gunther Maier) 


\section{$\mathbf{W}$}

